\title{
Multiphase magmatic activity in the Variscan Kłodzko-Złoty Stok intrusion, Polish Sudetes: evidence from SHRIMP U-Pb zircon ages
}

\author{
Petras Jokubauskas $^{1}$ [D $\cdot$ Bogusław Bagiński ${ }^{1} \cdot$ Ray Macdonald $^{1} \cdot$ Ewa Krzemińska $^{2}$
}

Received: 19 July 2016 / Accepted: 16 November 2017 / Published online: 30 November 2017

(c) The Author(s) 2017. This article is an open access publication

\begin{abstract}
The Kłodzko-Złoty Stok intrusion (KZSI), located in the NE part of the Bohemian Massif of Central Europe, has preserved records of the magmatic and tectonic activity of the Variscan orogeny in the Sudetes. KZSI is extraordinarily complex texturally, and shows a very wide range of chemical, isotopic and mineralogical compositions which indicates a complex, multiphase history of intrusion. New SHRIMP U-Pb zircon ages provide evidence of two magmatic episodes with a distinctive hiatus between them at $\sim 326-308 \mathrm{Ma}$. The youngest dated zircons (303.8 \pm 3.8/4.2 Ma) are from the Laski leucocratic hornblende-biotite monzogranite and mark a short interval of post-collisional reactivation of the magma system. Zircons from a biotite-hornblende diorite sheet from the northern part of KZSI yielded an age of 349 $\pm 3.4 / 3.7 \mathrm{Ma}$, interpreted as indicating the initial phase of an early Carboniferous, multi-pulse episode. The evolution of the magmatic system can be tied to a 334.4 $\pm 2.9 / 3.3$ Ma zircon age for melanocratic syenites from Podzamek which represent lamprophyric melt. Based on textural and compositional data and field relationships we interpret the intrusion as having been tilted post-emplacement towards the NW. This, together with the new dating results, ties the early Carboniferous episode of KZSI activity and the Jawornik granitoids ( $5 \mathrm{~km}$ to the SE) to the same magmatic system and arguably to bentonites of the Paprotnia beds (5 km to the NW), all representing different levels of such a system. The newly estimated late Carboniferous age from Laski ties part of the KZSI to other late Carboniferous Sudetic intrusions and late Carboniferous-Permian volcanism.
\end{abstract}

Keywords Kłodzko-Złoty Stok intrusion · SHRIMP geochronology · Variscan granitoids $\cdot$ Lit-par-lit emplacement $\cdot$ Postemplacement tilting

Electronic supplementary material The online version of this article (https://doi.org/10.1007/s00531-017-1562-x) contains supplementary material, which is available to authorized users.

Petras Jokubauskas

klavishas@gmail.com

Bogusław Bagiński

b.baginski1@uw.edu.pl

Ray Macdonald

r.macdonald@lancs.ac.uk

Ewa Krzemińska

ekrz@pgi.gov.pl

1 Institute of Geochemistry, Mineralogy and Petrology, Warsaw University, al. Żwirki i Wigury 93, 02-089 Warsaw, Poland

2 Polish Geological Institute, National Research Institute, ul. Rakowiecka 4, 00-975 Warsaw, Poland

\section{Introduction}

The Kłodzko-Złoty Stok intrusion (KZSI), located in the NE part of the Bohemian Massif (BM) of Central Europe (Fig. 1), has preserved records of the magmatic and tectonic activity of the Variscan orogeny in the Sudetes. KZSI has a considerable variety of igneous rocks, ranging mainly from diorite to monzogranite and syenite with some less abundant gabbro and ultrabasic rocks (Wierzchołowski 1976). The intrusion is cut by abundant melanocratic dykes (Fig. 1) ranging from andesite-dacite-like (microdiorite) to lamprophyres (minette, spessartite, vogesite) and lamprophyroids (Wojciechowska 1975; Wierzchołowski 1977, 2003; Awdankiewicz 2007). The relationship between dykes and the main granitoids is not clear-there are opposite views as to whether the intrusion was or was not completely solidified during dyking (Wojciechowska 1975; Wierzchołowski 1977; Cwojdziński 1981; Lorenc 1994; Awdankiewicz 2007). Finally, the intrusion contains abundant enclaves of 


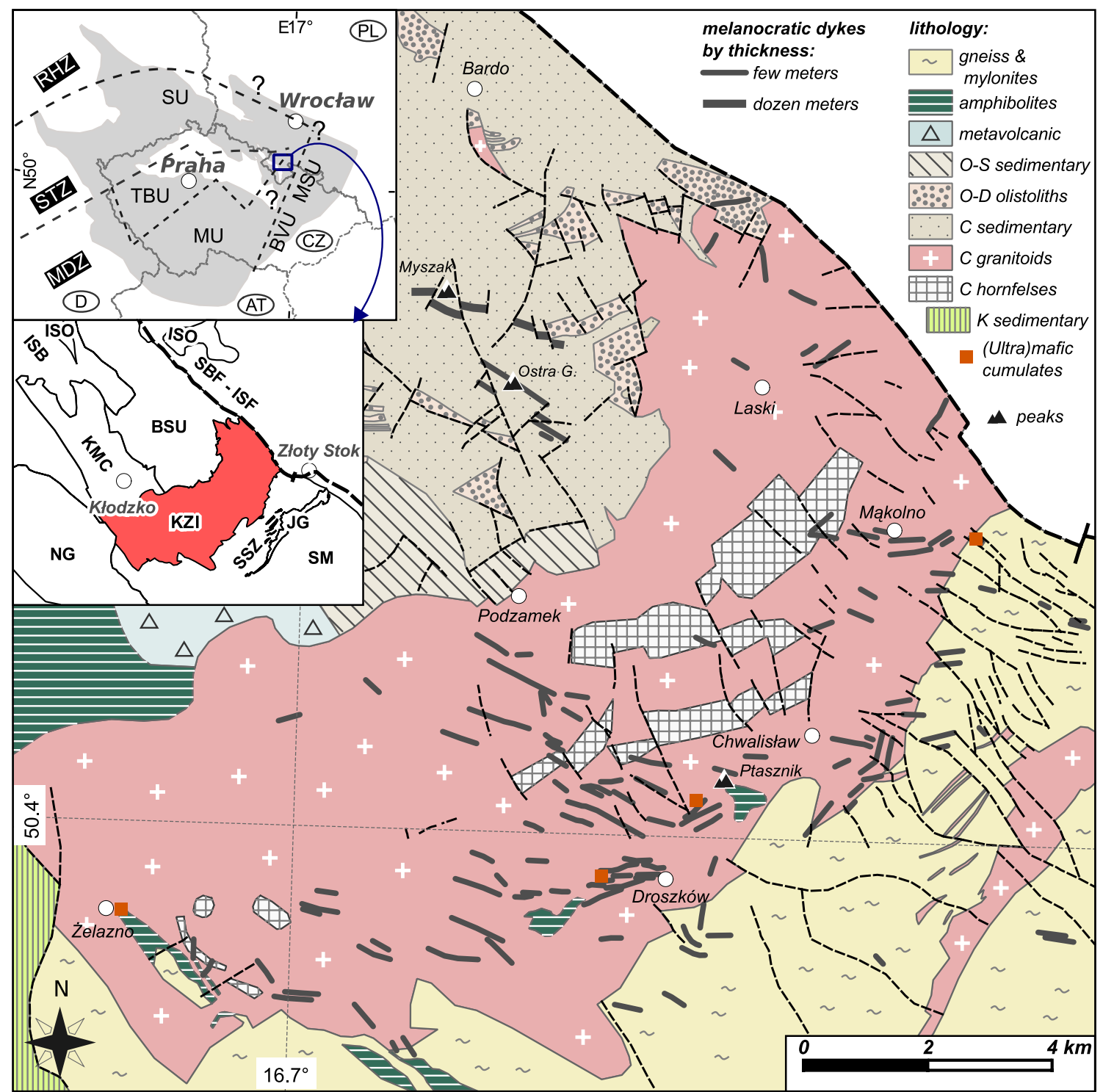

Fig. 1 Geological sketch map of the Kłodzko-Złoty Stok intrusion, wall rocks, melanocratic dykes, and faults based on Finckh et al. (1942), Wojciechowska (1975) and Cwojdziński 1979, and its position in the Bohemian Massif. ISO intra-Sudetic ophiolite, ISB intraSudetic basin, $B S U$ Bardo sedimentary unit, $K M C$ Kłodzko metamorphic complex, $N G$ Nysa Graben, $K Z I$ Kłodzko-Złoty Stok intrusion, SSZ Złoty Stok-Skrzynka shear zone, $J G$ Jawornik granitoids, SM

different shapes (Wierzchołowski 1976), some of which have been identified as mafic magmatic enclaves (MME) (Lorenc 1994) and point to the mixing of intermediate (granodioritic) and mafic magmas (Lorenc 1991, 1994; Holub and Żaba 2003). In particular, double-lobed MME (Lorenc 1994) and complex streak zones (Jokubauskas et al. 2014c) were formed by recurrent magma injections and mixing, suggesting multi-pulse magma replenishment of the intrusion.

The first issue which this paper addresses is: how long was the KZSI active and if there are any significant age
Śnieżnik Massif, SBF-ISF Sudetic boundary fault-intra-Sudetic fault; tectonic zones: $R H Z$ Rhenohercynian, STZ Saxothuringian, $M D Z$ Moldanubian; lithotectonic units in the Bohemian Massif: $S U$ Saxothuringian, $T B U$ Teplá-Barrandian, $M U$ Moldanubian, $B V U$ Brunovistulian, $M S U$ Moravosilesian; single letters in lithology represent geological epochs: $C$ Carboniferous, $D$ Devonian, $O$ Ordovician, $S$ Silurian

differences between the contrasting rock types? Previously published zircon $\mathrm{U}-\mathrm{Pb}$ ages tried to deal with the issue (Mikulski and Williams 2013; Mikulski et al. 2013; Oberc-Dziedzic et al. 2015; Budzyń and Jastrzębski 2016); however, most of the results were for intermediate (granodiorite) and mixed rocks. To answer the question more fully, we aimed for SHRIMP dating of end-member or singletype magmas representing rocks which none of the previous studies had addressed. We applied the SHRIMP U-Pb zircon dating method to rocks with well-preserved zircons 


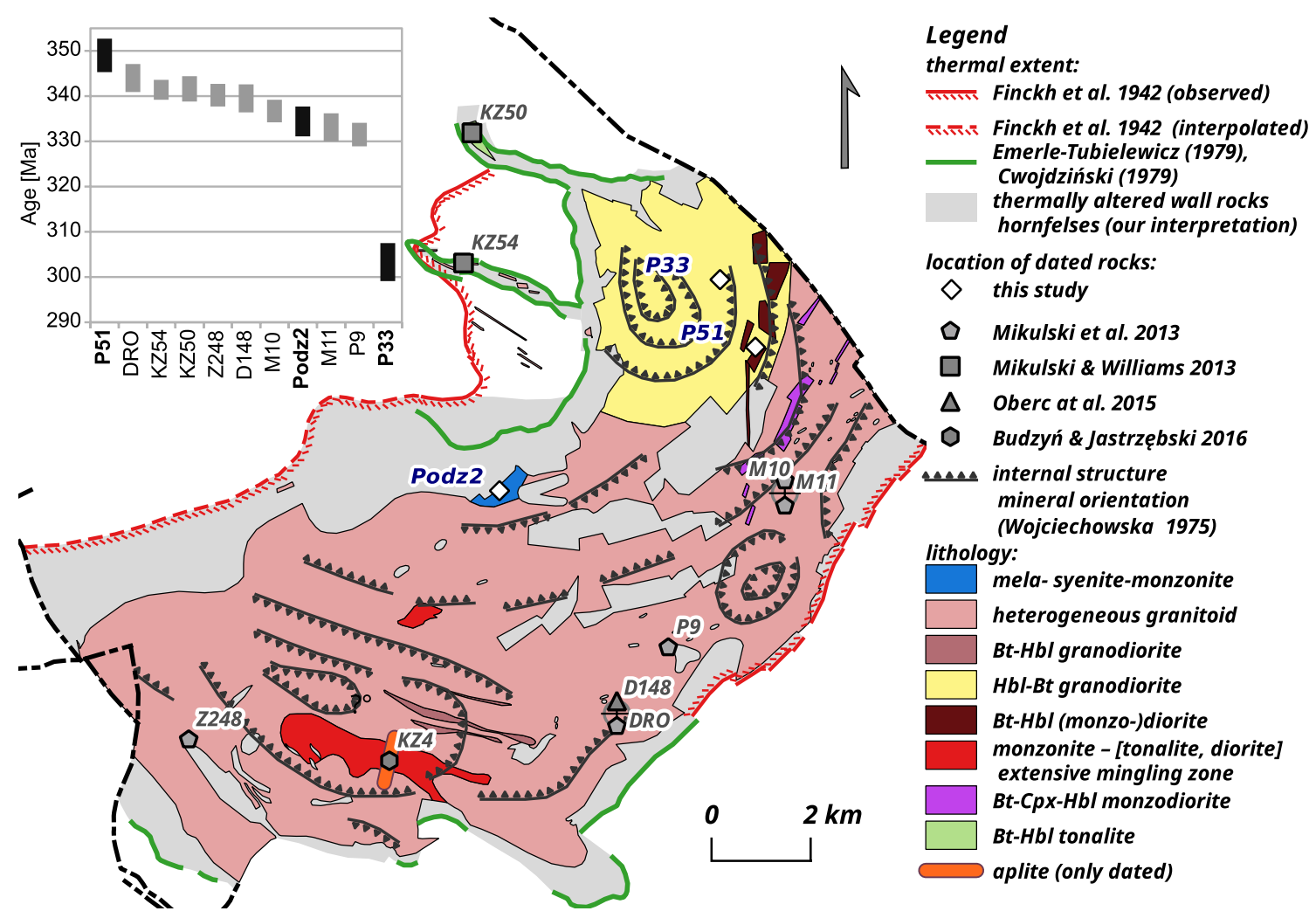

Fig. 2 Map of the distribution of lithologies and the structure of the KZSI; the sketch is based on this study and that of Wierzchołowski (1976). Note the generally parallel elongations of the different kinds of structure and the internal mineral elongation depicted by Wojciechowska (1975) and collision of "dome" structures with other lithologies. Inset compares the available dating results. The sample represents different kinds of rocks: $\mathrm{P} 33-\mathrm{Hbl}-\mathrm{Bt}$ monzogranite (this study), P84-Bt aplite (this study), KZ4-Bt aplite (Budzyń and

showing as little inheritance as possible, which has led to a straightforward interpretation of the results. We have also compiled a new map based on the most detailed earlier studies (Beyrich et al. 1865; Finckh et al. 1942; Wieser 1958; Wierzchołowski 1976) which we cross-checked with our own observations (Fig. 2).

The second issue considered here is the relationship of KZSI to the closest igneous rocks of the same age emplaced in the same (semi-)continuous tectonic block. Based on a literature review (see below) and our observations, we can suggest that the region (of at least $15 \mathrm{~km}$ length) was tilted after KZSI emplacement, where the attendant erosion created a "cross-section" through the continental crust with magmatic bodies in place, providing an opportunity to better understand the interactions between pluton, dykes and volcanism.

Finally, the prolonged magmatism of KZSI must ultimately be explained in the regional geological context. Any interpretation of the relevant tectonic regime must, however, be based on a synthesis of all petrographic, mineral chemistry, geochemical and isotopic data (to be published
Jastrzębski 2016), P9—-tonalite (Mikulski et al. 2013), M11—spessartite (Mikulski et al. 2013), Podz2-melanocratic syenite/monzonite (this study), D148-monzonite (Mikulski et al. 2013), Z248-Qtz monzodiorite (Mikulski et al. 2013), KZ54-Cpx-Opx microdiorite (Wierzchołowski 1976; Mikulski and Williams 2013), KZ50-BtHbl tonalite (Mikulski and Williams 2013), DRO—unclassified granitoid (Oberc-Dziedzic et al. 2015), P51-Bt-Hbl diorite (this study)

elsewhere). We report here only on some recognized patterns which place the KZSI in a particular group of Variscan intrusions from the Bohemian Massif. We hope that will help the KZSI to be correctly included in the next generation of geodynamic models.

\section{Regional geological setting}

The geology of the Central European part of the Variscan orogenic belt reflects the convergence of Gondwana and Laurasia at 380-280 Ma (Finger and Steyrer 1990; Matte et al. 1990; Dallmeyer et al. 1995; Franke 2000, 2006; von Raumer et al. 2014). The region is classically divided into three major tectono-stratigraphic units, the Rhenohercynian, Saxothuringian and Moldanubian zones (Fig. 1). In more detail, the BM is subdivided into five units (termed, by different authors, domains, terrains, blocks or zones): Saxothuringian (SU), Moldanubian (MU), Teplá-Barrandian (TBU), Brunovistulian (BVU) and MoravoSilesian (MSU). The 
Variscan orogeny is represented in Poland by the Sudetes and their foreland. The projection of the mentioned units into the Sudetes is not universally agreed (Aleksandrowski and Mazur 2002; Winchester et al. 2002; Kryza et al. 2004; Klomínský et al. 2010; Chopin et al. 2012; Oberc-Dziedzic et al. 2015). We favor Franke's $(2012,2014)$ unit projection where the Sudetes are attached to the Saxothuringian, Teplá-Barrandian and Moldanubian units, corresponding to the west, central and east Sudetes (Mazur et al. 2006; ObercDziedzic et al. 2015). The KZSI is emplaced between the east and central Sudetes (Oberc-Dziedzic et al. 2015).

It has been considered that the main deformation in the area occurred at the Middle- to Late Devonian boundary, when the Sudetes collided with the Brunovistulian block and was followed by regional uplift and a succession of Carboniferous tectonothermal events (Chopin et al. 2012; Jastrzębski 2012; Jastrzębski et al. 2013; Gordon et al. 2005). There are two opposing models describing the mechanics of the east-central Sudetes and Brunovistulian unit collision, where the Brunovistulian block subducted under the Sudetes (Schulmann and Gayer 2000) or the Sudetes (as part of the Saxothuringian unit) subducted under the Brunovistulian block (Chopin et al. 2012).

The Bohemian Massif was the site of episodic granitoid plutonism, with several peaks of magmatic activity, during a period of > $70 \mathrm{Ma}$ (Janoušek and Žák 2015). Earlier radiometric dating suggested that the granitoids were emplaced in the Sudetic Block during two separate periods, syncollisional 340-330 Ma and post-collisional 320-300 Ma (Franke and Żelaźniewicz 2000; Mazur et al. 2007). At first glance, the newer compilation of igneous ages indicates that the igneous activity was rather continuous over the period 351-285 Ma (Fig. 13 in Mikulski et al. 2013; Fig. 12 in Laurent et al. 2014); however, the gap between the two periods is filled only with numerous SHRIMP U-Pb zircon dating results from the Karkonosze pluton (from $328 \pm 12$ to $303.7 \pm 6.6 \mathrm{Ma}$ ). Those results were demonstrated to have been influenced by numerous methodological shortcomings (Kryza et al. 2014). With chemical abrasion ID-TIMS U-Pb zircon (Kryza et al. 2014) and SHRIMP U-Pb monazite dating results (Kusiak et al. 2014), the time span of Karkonosze magmatic activity can be significantly reduced to $<1 \mathrm{Ma}$, or a few Ma (with monazite dating) at ca. $312 \mathrm{Ma}$. In that case, the hiatus between episodes is not blurred and the division proposed by Franke and Żelaźniewicz (2000) and Mazur et al. (2007) is still valid.

\section{The Kłodzko-Złoty Stok intrusion}

The KZSI has an outcrop area of $\sim 120 \mathrm{~km}^{2}$ and is roughly crescent shaped (Figs. 1,2). The intrusion (where KZSI is presented under the term "syenite of Glatz-Reichenstein") and its shape were used as an example of a phacolithic intrusion in the first English scientific publication mentioning the KZSI (Balk 1925). In contrast, Wojciechowska (2002) argued that the contacts with the country rocks are intrusive and discordant.

Enclaves up to a few $\mathrm{km}$ in size in the intrusion are taken to be roof pendants (Wojciechowska 1975). Those in the western part of the body were part of the Bardo sedimentary unit (BSU) and the Kłodzko metamorphic complex, whereas those in the SE are relics of Orlica-Śnieżnik metamorphic rocks (Cwojdziński 1979).

Three dome-like structures were proposed within the body, on the basis of elongated mineral fabrics that correspond to the orientation of $\mathrm{F} 3$ folds in the cover rocks (Wojciechowska 1975). Wojciechowska (1975) interpreted these structures as indicating three pulses of magma emplacement. However, many observed inconsistencies such as conflicts with mega-enclave position or other granitoid lithologies (Fig. 2), the dominant mineral orientation measurements following the intrusion shape with missing measurements needed to close the dome structure (Fig. 3 in Wojciechowska 1975), as well as the study by Lorenc (1994), point to rather sheet-like (lit-par-lit) structures in the southern part of the intrusion (see below). Only the northern dome can be argued to be a real feature (particularly considering the results of this study).

The northern boundary of the KZSI is defined by the Sudetic Boundary Fault, separating it from the Fore-Sudetic Block (Wojciechowska 1975) (Fig. 1). To the NW and W, the intrusion is in sharp contact with the BSU, which consists largely of non-metamorphosed Devonian to Early Carboniferous sedimentary rocks (Kryza et al. 2008b; Muszer and Uglik 2013; Bojanowski et al. 2014), and by the greenschist-to amphibolite-facies rocks of the Kłodzko metamorphic complex (Mazur et al. 2004), metamorphosed in the Early Palaeozoic to pre-Late Devonian (Wojciechowska 1975). The BSU overlies (with a sedimentary contact) the Kłodzko metamorphic complex (Kryza et al. 2008a).

The KZSI is bordered on the SE by the Orlica-Śnieżnik Dome (OSD), which consists of Middle Cambrian-Early Ordovician metamorphic rocks (Jastrzębski et al. 2010; Żelaźniewicz et al. 2014). The eastern boundary is the Variscan Złoty Stok-Skrzynka shear zone (SSZ), a 4-km-wide zone of mylonites, cataclasites, gneisses and schists (Cymerman 1996; Aleksandrowski 1998). Some metamorphic rocks of the OSD, especially in the migmatized zones, include zircon populations that yielded U-Pb ages of $360-330 \mathrm{Ma}$ (Klemd and Bröcker 1999; Bröcker et al. 2009; Żelaźniewicz et al. 2014), indicating that at that time the dome was still deeply buried.

The Jawornik granitoids (JG) lie within the SSZ, a few $\mathrm{km}$ to the east of the eastern KZSI border (Fig. 1). They form a NE-SW trending body, up to $1.2 \mathrm{~km}$ wide and 

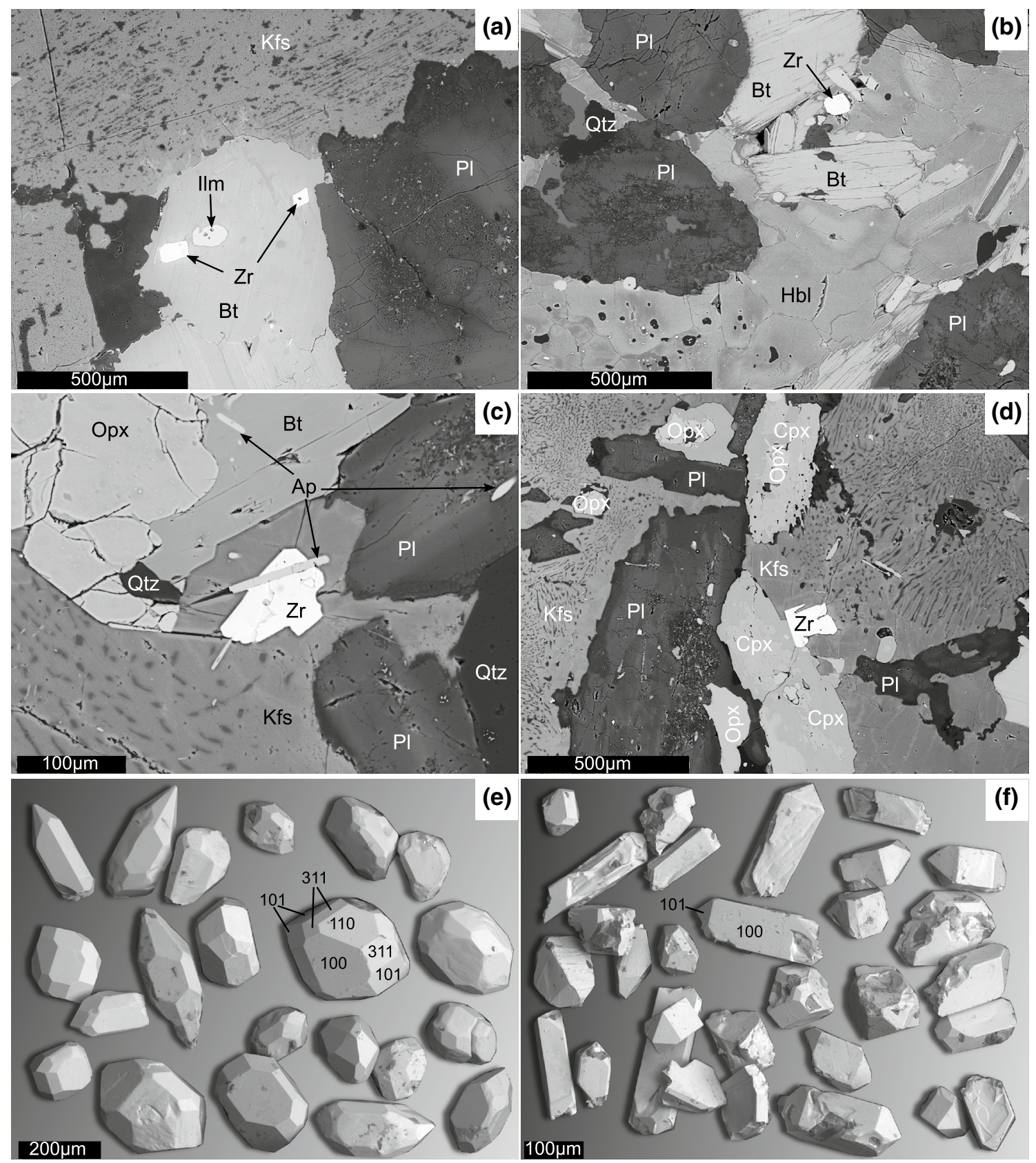

Fig. 3 BSE images of typical zircons from the studied samples: a sample P33 zircons in Hbl-Bt monzogranite; b P51 zircons in Bt-Hbl diorite; $\mathbf{c}, \mathbf{d}$ BSE image of Podz2 zircons in Qtz Bt-Hbl-Cpx syenite;

note the overgrowth on zircon of other minerals (apatite); e BSE topo image compilation of typical P51 zircons; $f$ BSE topo image compilation of typical Podz2 zircon

$12 \mathrm{~km}$ long, elongated along the shear zone in the NE portion of the OSD. Generally, the JG comprise two rock types: biotite-hornblende granodiorites and muscovitehornblende granodiorites (Białek 2001). A Pb-Pb single zircon evaporation age of an amphibole-biotite granodiorite yielded an age of $353 \pm 1 \mathrm{Ma}$ (Skrzypek et al. 2014). CHIME dating of monazite from a muscovite-biotite granodiorite and host metamorphic rocks points to an

emplacement age ( $343 \mathrm{Ma})$ within the age range of the KZSI (Budzyń et al. 2015; Budzyń and Jastrzębski 2016). This may indicate that the KZSI and Jawornik bodies were part of the same magmatic system. Budzyń and Jastrzębski (2016) argue that magma emplacement was synchronous with a regionally dominant tectonic-metamorphic event in the shear zone. 


\section{Range of rock types and their relationships}

For a relatively small body, compared to the other intrusions in the BM, the KZSI contains a large range of lithologies: the main types are monzonite, quartz monzonite, monzodiorite, diorite, granodiorite, syenite and monzogranite. Figure 2 shows, in a much simplified form, the distribution of the main rock types. However, transitions between them are very rapid and show a complexity created mainly by magma mixing between two main components; mingling of primary basaltic melts (or fractionated dioritic-tonalitic magmas) and primitive lamprophyric melts (or more evolved monzonitic-syenitic magmas) formed widespread streaks and enclaves, in some cases even double-lobed enclaves (Lorenc 1991, 1994). Both types of magma can occur as enclaves, in varying proportions: the most abundant products of mixing are hybrid melanocratic granodiorite and monzodiorite-the most common lithologies in the intrusion. Other rock types occur in limited sizes and cannot be shown on the map; however, the type and position of those rocks in the KZSI are the key to understanding the structure of KZSI (Fig. 6).

On the basis of the regional geological map of Beyrich et al. (1865), the detailed geological maps of Finckh et al. (1942) and Wieser (1958), the petrographic study by Wierzchołowski (1976) and the results of the present investigation, some large structures in the major lithologies can be distinguished. In some parts of the intrusion, large batches of monzonitic melt form extensive mingling zones and monzonitic sheets. Both types of structure are elongated in line with the crescent (phacolithic) shape of the intrusion. The most common type of monzonite is fine-grained, sometimes porphyritic with plagioclase or alkali feldspar crystals up to $2-3 \mathrm{~cm}$. Generally, a transition between the two varieties correlates with the degree of mixing, with the porphyritic form representing the most extensive mingling. The melanocratic syenites at Podzamek (Fig. 2) are the only known occurrence of this rock type in the Polish Sudetes, although they are not uncommon elsewhere in the Bohemian Massif where they are termed durbachites or appinites (Rock 1991; Bowes and Košler 1993). They are believed to have crystallized directly from lamprophyric magmas. Rocks from Podzamek show some limited evidence of magma mixing and, where present, the mixing consists of microenclaves carrying phlogopite-clinopyroxene-spinel-(Ni, Co, Fe)S assemblages. The very close genetic connection with lamprophyres, the clearly igneous origin of the zircons (see below) and the lack of any previous age estimations make these rocks a prime candidate for this study.

The other type of primary magma, represented by sheets of diorite, is known only from the NE part of the intrusion. The sheets, dislocated into a few separate parts (up to $\sim 1 \mathrm{~km}$, Fig. 2), follow the phacolithic orientation of the intrusion. The rocks have a strongly oriented fabric which, based only on macroscopic observations, can lead them to be mistaken for gneisses (e.g., Beyrich et al. 1865). There are no exposed contacts between the diorites and the other intrusive rocks but a rapid change in the nature of boulders on the surface suggests a very sharp transition. The map and inset stratigraphical scheme in Finckh et al. (1942) presented these rocks as the second layer from the bottom of a granitoid body-one of the initial layers of intrusion. Later, these rocks were reinterpreted as dykes (Cwojdziński 1977; Wojciechowska 1975). Thus, naturally the rock was seen by us to be a very interesting candidate for zircon dating which would verify which of the previously contrasting interpretations was correct. It also appeared to be the most promising candidate for the oldest KZSI rock.

Biotite-hornblende tonalites have been recorded at Ptasznik Hill in the south-central part of the intrusion (dated by Mikulski et al. 2013) and as an apophysis from Bardo (Figs. 1, 2, dated by Mikulski and Williams 2013). They are of different age (see below), suggesting that tonalite production spanned much of the lifetime of the KZSI. Compositionally similar, but mineralogically different (two pyroxenes), microdiorites/basaltic andesites in the Bardo Mountains represent early hybrid basaltic-granodioritic magma [crystal mush was identified as syenogabbro and dated by Mikulski and Williams (2013)].

The northern part of the KZSI is less heterogeneous than the rest of the body. It was recognized as being more felsic than the rest of the intrusion more than a century ago by Beyrich et al. (1865). However, this simple and quite important distinction was omitted from Finckh et al.'s (1942) detailed maps, and was never later presented. The century-old distinction can be defended using the modern petrographic dataset of KZSI, with good spatial coverage, from Wierzchołowski (1976). The main rock type is hornblende-biotite granodiorite with some subordinate granite, pegmatite and aplite occurrences. Xenoliths and magmatic enclaves are abundant; however, no lamprophyre dykes have ever been found in this part, while they are quite abundant in other parts of the intrusion. Surprisingly, there have been no previous dating attempts of this distinctive part of the intrusion, so it was included for zircon dating in this study.

Bodies up to a few $100 \mathrm{~m}$ long of mafic/ultramafic rocks, often outcropping as large blocks (1-2 m), occur in a few places on a NNE-SSW trending line on the E-SE side of the intrusion (Muszer 1992; Hamdy 2001; Gunia and Wojciechowska 2002). The most ultramafic varieties (olivine-hornblende-phlogopite-pyroxenites) occur near/at the contact between the KZSI and a carbonate lens from the OSD or the SSZ. Less ultramafic 
types (pyroxene-olivine-phlogopite hornblendites and olivine-pyroxene-hornblende phlogopitites) are located within the granitoids. Those (ultra-)mafic rocks are rather cumulates of lamprophyric melts, and cannot be tied directly with hornblende-clinopyroxene gabbros from the SW part of the KZSI (Żelazno) which are of granitoid affinity. The grading of gabbros to monzodiorite suggests a later interaction with lamprophyric melts, on the basis of clinopyroxene-hornblende replacements and on the presence of titanite overgrowths enriched in $\mathrm{Zr}$ (Seifert and Kramer 2003; Ventura et al. 1999).

According to Wojciechowska (1975), the KZSI is cut by aplites, pegmatites and various melanocratic dykes, the latter including porphyritic microdiorites and different varieties of lamprophyres and lamprophyroids. Wierzchołowski (1977) argued that the porphyritic microdiorite, aplites and pegmatitic veins were closely related to the main phase of the intrusion, but that the lamprophyres were emplaced later. In contrast, Awdankiewicz (2007) suggested, from mineralogical, geochemical, and isotopic evidence, that the lamprophyres and microdiorites are closely related and that, on the basis of cross-cutting relationships and evidence of brittle emplacement, the dykes were generally later than the main body. However, the mafic components of the mixed magma rocks within the mass are very similar petrographically and texturally to lamprophyres and we suggest that lamprophyric magma was available throughout much of the history of the KZSI. The lamprophyres (spessartite-vogesite) are common as dykes and sheets, and occur mostly in the south, east and SE parts of the KZSI and in the OSD perpendicular to the KZSI. None is known in the northern part of the intrusion or in the BSU.

The lamprophyre bodies parallel and perpendicular to the crescent-shaped KZSI could have formed at the same stage as the sheets and dykes (Figs. 1,2). Various relationships with the host granitoid rocks have been reported (Awdankiewicz 2007; Wierzchołowski 1976; Lorenc 1994); they vary from sharply intrusive to transitional in mingling textures, which probably points to a few generations of lamprophyric dykes (syn-igneous and postintrusive). Zircon dating of these rocks is very complicated as they rarely contain zircon. Even when zircons are present, attempts to date them (Mikulski et al. 2013) have shown mixed results, where the presence of abundantly inherited, older, crustal zircons raises the question whether the population of youngest zircons is not also inherited. Zircon U-Pb dating from lamprophyre dykes should in particular be approached very cautiously as zircon is not stable in lamprophyric melts (Seifert and Kramer 2003). Dating of lamprophyric melt can be attempted by dating the plutonic form of the same melt (if present), where zircon would have enough time to crystallize as the last phase (i.e., Podzamek syenite dated in this study, see the results).
Based on a spatial analysis of our and Wierzchołowski's (1976) petrographical data, microdiorites formed dykes only perpendicular to the intrusion. They occur in all parts of the body and in the Bardo Mountains (particularly on Góra Kłodzka; Fig. 1) but have not been reported from the OSD. The aplites can be separated into two groups, one parallel to the shape of the KZSI, the other perpendicular to it and following the NW-SE-trending faults. On the Bardo Mountains, both the main intrusion and the dykes are cut by faults, such that the perpendicular group is probably later. The parallel set of aplites is accompanied by lamprophyres in the southern part of the intrusion, suggesting perhaps a genetic connection or rather syn-tectonic emplacement. The pegmatites are very small and there is insufficient information on which to divide them into separate groups. The main occurrences are near the NW contact of the intrusion (Wierzchołowski 1976); elsewhere they are rare. One of the widest aplite dykes (ca. $20 \mathrm{~m}$ wide) was selected for dating; however, the separated abundant zircons were unacceptably metamicticized, making them non-datable.

Finally, the KZSI hosts a wide range of xenoliths of different size and composition. Mostly they are hornfelses and amphibolites (Wierzchołowski 1976; Bachliński and Bagiński 2007). The size varies from hardly identifiable (a few mm or smaller) up to blocks a few kilometers across, which, according to Wojciechowska (2002), are roof pendants of surrounding rocks (metavolcanics of the BSU, Bardo sedimentary rocks, amphibolites). We will show them below to be remnants of wall rocks trapped between different sheets (Fig. 6). The shape of small xenoliths varies from blocky, cigar-shaped to perfectly rounded (Wierzchołowski 1976; Lorenc 1991). Cwojdziński (1979) observed that the compositions of megaxenoliths resemble the Kłodzko Metamorphic Complex and OSD rocks on the NW and SE sides accordingly. Most of the megaxenoliths underwent contact metamorphism, where temperatures estimated using different geothermometers reached $750{ }^{\circ} \mathrm{C}$ or locally up to $880^{\circ} \mathrm{C}$ (Bagiński 2002). Such high temperatures might suggest the melting of, and contamination by, xenolithic material; however, geochemical data (to be published elsewhere) suggest very little or no geochemical influx to the bulk composition of the intrusion.

\section{Radiometric dating}

The U-Th- $\mathrm{Pb}$ geochronological isotope system theoretically allows the use of three independent decay chronometers. Due to the small concentrations of some isotopes or to measurement difficulties, common SHRIMP zircon dating procedures include the measurement of only a limited set of isotopes ${ }^{238} \mathrm{U},{ }^{208} \mathrm{~Pb},{ }^{207} \mathrm{~Pb},{ }^{206} \mathrm{~Pb},{ }^{204} \mathrm{~Pb}$ and compounds $\left(\mathrm{UO}_{2}\right.$, $\mathrm{ThO}_{2}$ ). The rest of the requisite isotope ratios are calculated 
at the post-processing step from the measured data, using the internationally agreed constants of the isotope ratios (Williams 1998).

We have carefully compared our zircon dating results with those of previous studies. All dates presented and compared below will be ${ }^{204} \mathrm{~Pb}$-only-corrected ${ }^{1}$ without ${ }^{206} \mathrm{~Pb}$ or ${ }^{208} \mathrm{~Pb}$ corrections, and for comparison and for representing ages we will use only ${ }^{206} \mathrm{~Pb} /{ }^{238} \mathrm{U}$ isotope dates based on direct isotope measurement. All the results (including ${ }^{206} \mathrm{~Pb}$ and ${ }^{208} \mathrm{~Pb}$ ) are provided in Online resource 1 .

\section{Analytical methods}

Before zircon and monazite separation, 60 selected thin sections from the whole intrusion were investigated under an optical microscope and an SEM JeolJSM-6380LA in the Warsaw University Faculty of Geology. Four samples were selected for this study: Podz2-a melanocratic syenite representing fractional crystallization from lamprophyric melt, P51 - the most amphibole-rich diorite, P33 - the most leucocratic monzogranite from Laski [also we aimed to date the "dome" in Laski described by Wojciechowska (1975)], P84-the widest aplite dyke cutting the intrusion following the same direction as lamprophyre sheets and the main body of the intrusion.

The same Jeol SEM was used for morphological imaging of selected zircon separates (Fig. 3 e, f). The mounts with polished sample and standard (Temora2) zircon grains were tile-scanned with an optical microscope in reflected light mode. BSE (and CL for P33) tile-scans were acquired on the HITACHI SU3500 SEM. The same instrument was used to get more detailed CL after SHRIMP analyses. BSE images of analysed grains were taken with a Zeiss Auriga FE-SEM at the Cryo-SEM laboratory at University of Warsaw. Taking CL before SHRIMP analyses for Podz2 and P51 was considered unnecessary as zircons from Podz2 sample were evidently among the last phases to crystallize and the instability of zircon in lamprophyric melt (Seifert and Kramer 2003) and our SEM observations prevent the presence of inherited zircon cores; our SEM observation showed zircons from sample P51 to be very homogeneous-no core was found in any observed zircon.

$\mathrm{U} / \mathrm{Pb}$ isotope ratios of zircon were measured on the SHRIMP-IIe at the Polish Institute of Geology (PIG-PIB) in Warsaw. The measurements were proceeded by the exact method of Williams and Claesson (1987), where Temora2 zircons (Black et al. 2004) were used as reference material. The whole analytical procedure is present in Online resource

\footnotetext{
${ }^{204} \mathrm{~Pb}$ correction has nearly no influence on the results as raw counts of ${ }^{204} \mathrm{~Pb}$ mass completely overlap within one sigma with measured background counts from all analysed spots.
}

1 and detailed results are given in Online resource 2. The data reduction and error calculations were done with SQUID 2 and ISOPLOT (Ludwig 2009, 2012) excel-plugins, but high-quality plotting was done using python ${ }^{\mathrm{TM}}$ custommade scripts using the matplotlib (Hunter 2007) library. Age uncertainties reported here are on the $95 \%$ probability level, with analytical-only and calibration uncertainties-included, separated with a slash. No additional external errors (like decay constant uncertainty) were propagated, as all ages compared in this paper are $\mathrm{U}-\mathrm{Pb}$ ages.

\section{Description of analysed samples}

\section{Syenite of Podzamek (Podz2)}

The melanocratic biotite-(olivine/orthopyroxene)-clinopyroxene \pm quartz syenite/monzonite was formed by fractional crystallization of lamprophyric melts. Based on textures, magnesian biotite, olivine and clinopyroxene crystallized first. Cores of plagioclase are hosted in poikilitic K-feldspar granophyric intergrowths which are present in orthopyroxene-bearing rocks. Such rocks contain abundant zircons and were used for dating. Textural and geochemical evidence indicates that the zircon crystallized as one of the last phases (Fig. 3 c, d, f).

Compared to other KZSI samples, the Podzamek zircons are very different compositionally and morphologically. They are elongated 1:2-1:4 and have only well-defined $\{100\}$ faces with $\{101\}$ pyramids, with very rare and weak $\{110\}$ faces (Fig. 3e). Compositionally, the zircons are enriched in Th and $\mathrm{U}$, which increase toward the rims, with up to $\sim 2000 \mathrm{ppm} \mathrm{U}$ and $\mathrm{Th}$, whereas in the cores it is $100-300 \mathrm{ppm}$. This demonstrates that $\mathrm{Th}$ and $\mathrm{U}$ were extremely incompatible, and partitioned into the melt until the latest stages of crystallization. The general shift of the mean isotope ratio below the concordia line (Fig. 4, Pod2) is the effect of such fractionation, rather than $\mathrm{Pb}$ or $\mathrm{U}$ loss.

It should be mentioned that the $\mathrm{Th}-\mathrm{U}$ concentrations are below values where zircon damage would be observed (Gao et al. 2014; White and Ireland 2012), and, as can be seen in Fig. 4, are actually optimal and give less deviation. No relict cores were found.

\section{Diorite of Laski/Mąkolno (P51)}

The diorite contains up to $70 \%$ amphibole, which overgrows partly chloritised biotite. Plagioclase cores are highly sericitised. Based on textures, plagioclase and hornblende crystallized at the same time; minor amounts of K-feldspar and quartz are late interstitial phases. Zircon and apatite are hosted in all minerals. 


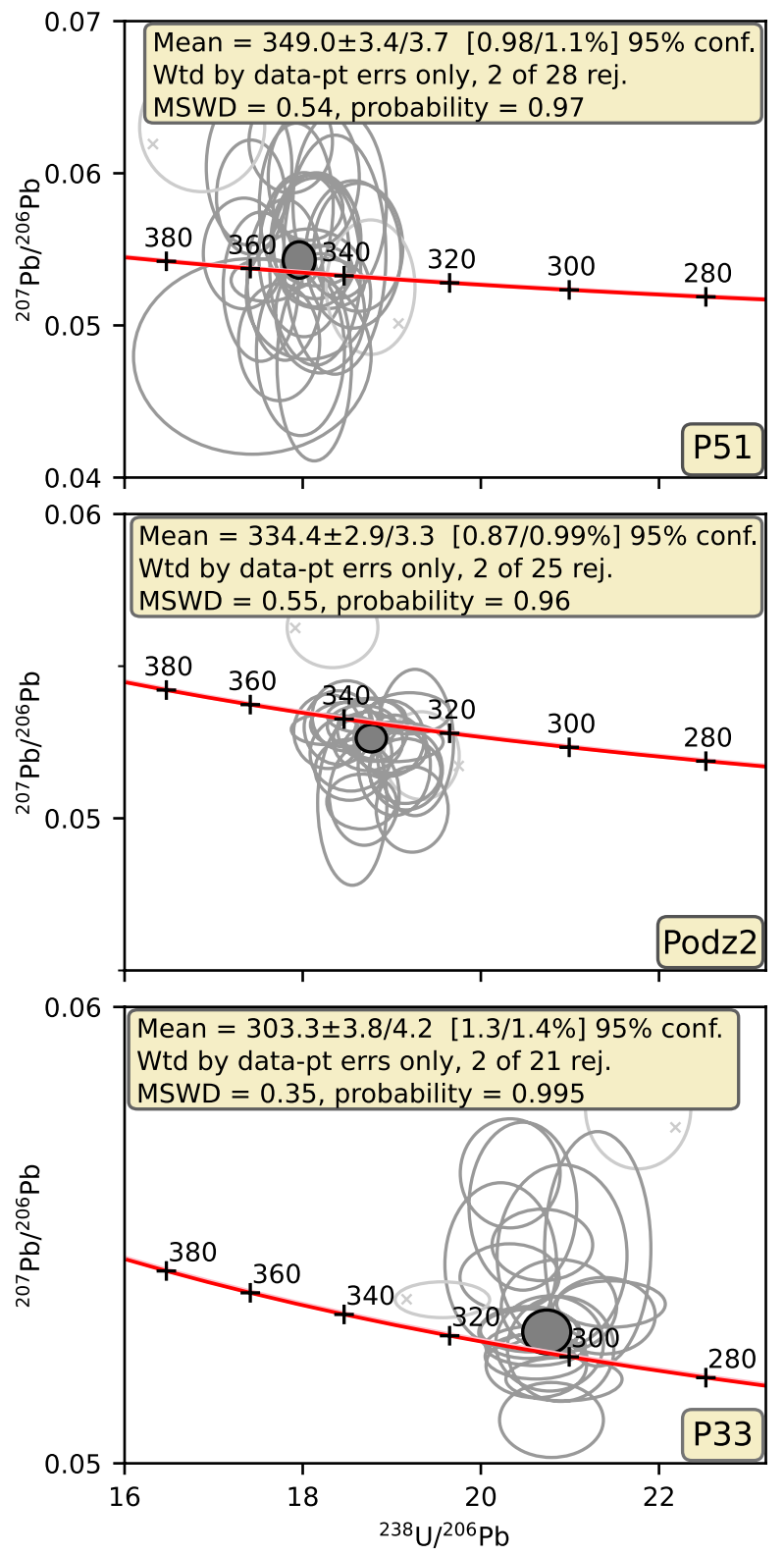

Fig. $4 \mathrm{U}-\mathrm{Pb}$ zircon SHRIMP dating results. Tera-Wasserburg type plots with shared $x$-axis for comparison; insets in plot present the mean ages calculated only from ${ }^{206} \mathrm{~Pb} /{ }^{238} \mathrm{U}{ }^{204} \mathrm{~Pb}$-corrected dates

The P51 zircons are very different to the zircons of the Podzamek syenite. Morphologically they contain all possible zircon faces, where $\{110,101,311,100\}$ dominate and with $\{110\}$ often being larger than $\{100\}$. The elongation ratio is also very atypical at $2-1.5$. There are rare relict cores; however, alteration rims are very often present, sometimes penetrating the zircon crystal to the core. In some section cuts, this could be misinterpreted as being relict. We investigated the SHRIMP analytical spots to ensure that no compromises to the dating results were propagated.

\section{Monzogranite of Laski (P33)}

The monzogranite of Laski represents the most felsic plutonic rock of the KZSI. Sample P33 is coarse-grained and dominated by K-feldspar, plagioclase and quartz. Plagioclase compositions range from oligoclase in the cores to albite at the rims. Biotite is the dominant dark mineral, at $\sim 10 \%$. Calcic amphibole is rare. The rock contains large $(1 \mathrm{~mm}$ ) allanite grains (with apatite, ilmenite and rare zircon inclusions) surrounded by unidentified REE carbonate (bastnaesite) rims. The zircon and fluorapatite concentrate mostly in the biotite and amphibole.

Some zircons have a type of brittle lobe (Fig. 5a). Most are very small, often less than $50 \mu \mathrm{m}$, making SHRIMP analysis challenging; only a small proportion of the crystals is $>100 \mu \mathrm{m}$. Morphologically, the zircons have similar faces to P50, but the elongation ratio is slightly higher $(1: 2-1: 3)$.

\section{Discussion of results}

\section{U-Pb dating}

A total of 74 SHRIMP spots were analysed in 58 zircon grains. In Fig. 4 we present the zircon dating results from this study only; our results are compared with those from previous studies in the inset of Fig. 2 and Table 1. While without any reduction our datasets have excellent MSWD, we decided to reduce every dataset by two points, which improves the probability, widens slightly the uncertainty (which we feel otherwise is under-estimated) while mean ages are not significantly affected (0.0-0.2 Ma). Rejection in percent of all points is equal to, or much less, than in previous studies (Table 1).

\section{Podzamek syenite}

The mean ${ }^{206} \mathrm{~Pb} /{ }^{238} \mathrm{U}$ age, with the rejection of two points from 25 in total, is $334.4 \pm 2.9 / 3.3$ Ma with a probability of 0.96 and MSWD of 0.55 . The result clearly shows that lamprophyric melts were involved at an early Carboniferous stage of the KZSI magma system. The lack of any features in cathodoluminescence (Fig. 5c) and very weak sectoring in BSE images allow a straightforward interpretation of the results as a single magmatic event. The age of the Podzamek syenite is very similar to the age of a lamprophyre (spessartite) from a previous study (Fig. 2; Table 1). With the new dating result from the Podzamek syenite, there is no doubt that lamprophyric melts coexisted with dioritic/tonalitic magmas. It should be noted that the age is that of just one 
Fig. 5 Zircon internal textures under BSE and CL: a sample P33. Note the small size, and typical magmatic oscillatory zoning, with rounded inner resorption textures; $\mathbf{b}$ large crystals of P51, where analytical SHRIMP spots are visible in BSE images; compared to P33 the zircons have very thin bright rims (in BSE) which are too small to analyze; however, the main zircon textures are less pronounced than in P33; c Podz2 zircons; note the one sideway oscillatory zoning which could indicate the zircon growth with one of the sides protected, and the lack of CL (the background is brighter than the crystals); also at lower left note the extremely resorbed relict which represents a disequilibrium texture, where remnants of the previous igneous texture are present. All scale bars are $100 \mu \mathrm{m}$

particular melt fraction, and younger or older lamprophyric melt fractions could also have existed.

\section{Diorite of Laski}

Zircon from P51 yielded an age of 349.0 \pm 3.4/3.7 Ma based on 28 analyses (2 rejected) with a probability of 0.97 and MSWD of 0.54. Without rejection of any data points, the mean age is younger by $0.2 \mathrm{Ma}$ but the probability then is lower (0.89); thus, we prefer the result based on the reduced dataset. It is the oldest reliable age from the KZSI, being based on 26 analyses.

\section{Monzogranite of Laski}

Zircons from P33 yielded an age of 303.3 $\pm 3.8 / 4.8$ Ma with a probability of 0.995 and MSWD of 0.35 based on 19 from 21 analyses. Without rejection of any analytical spots, the probability is unacceptably low (0.83) with MSWD of 0.70, where the age is practically the same (older by $0.1 \mathrm{Ma}$ and age error is smaller by 0.2 ). This new age differs significantly from any previous, or our, zircon results.

\section{Some implications}

\section{Time span}

The new SHRIMP zircon dating results are compared with published results in the inset of Fig. 2 and Table 1. There is a clear lack of any ages between $\sim 328$ and $\sim 308 \mathrm{Ma}$; thus, we should treat those as two separate events. 349-330 Ma is a long period of time for the main intrusive event. If the Jawornik granitoids were true precursors, the age range of the magmatic system during the main event can be expanded by up to $20 \mathrm{Ma}$.

The oldest P51 zircons, with a mean $349.0 \pm 3.4 / 3.7 \mathrm{Ma}$ age from diorites, mark the very beginning of magmatic activity at the KZSI intrusion level, whereas the Jawornik granitoids, situated at greater depth (Fig. 6), show evidence of initial magmatism at $351 \pm 1.3 \mathrm{Ma}$ (Białek 2014). It is not a coincidence that both bodies have the same NE-SW orientation, which we interpret as representing different
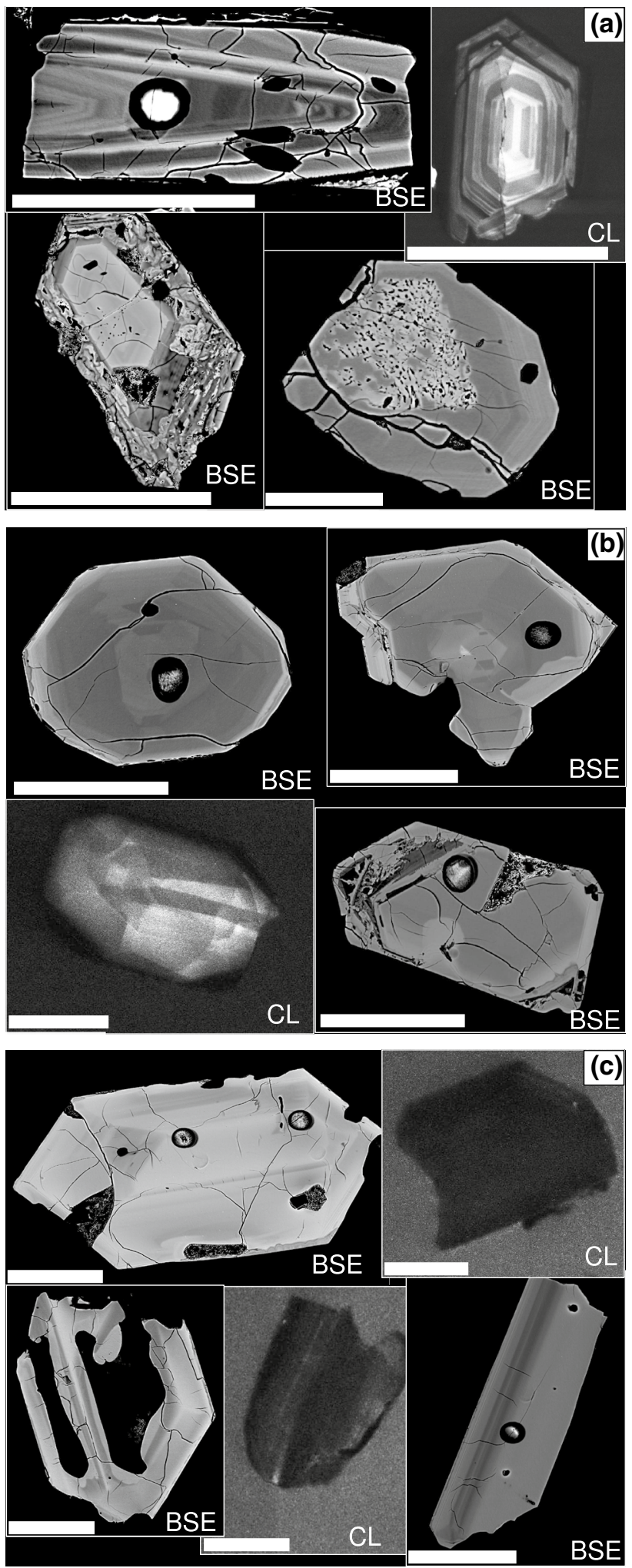

levels in the magma system. The Droszków monzonites and "granitoids" and monzonites from Żelazno are the second oldest known KZSI rocks. Those rocks are at the southern (SE and SW) part of the crescent shape of KZSI, where the 
Table 1 Comparison of available KZSI ages and its statistics (ordered by age); $N_{\mathrm{i}} / N_{\mathrm{a}}$ presents the portion of all analyses filtered down to fit into acceptable MSWD range (other studies) or to improve probability (this study, where MSWD without point rejection would still be acceptable)

\begin{tabular}{llllllll}
\hline Sample & Age (Ma) & $\mathrm{N}_{\mathrm{i}} / \mathrm{N}_{\mathrm{a}}$ & $\mathrm{N}_{\mathrm{i}} / \mathrm{N}_{\mathrm{a}}(\%)$ & MSWD & MSWD valid ${ }^{\mathrm{b}}$ & Rock & References \\
\hline P51 & $349.0 \pm 3.7$ & $26 / 28$ & 93 & 0.54 & Yes & Melanocratic Cpx-Bt-Hbl diorite & This study \\
DRO & $344.0 \pm 3.1$ & $8 / 12$ & 67 & 2.7 & No & "Granitoid"/monzonite(?) & Oberc-Dziedzic et al. (2015) \\
KZ54 & $341.4 \pm 2.2$ & $9 / 12$ & 75 & 1.6 & Yes & Syenogabbro/Opx-Cpx basaltic andesite ${ }^{\mathrm{a}}$ & Mikulski and Williams (2013) \\
KZ50 & $341.6 \pm 2.8$ & $12 / 12$ & 100 & 1.8 & Yes & Bt-Hbl tonalite & Mikulski and Williams (2013) \\
Z248 & $340.2 \pm 2.5$ & $11 / 12$ & 92 & 1.2 & Yes & Cpx-Bt-Hbl Qtz monzonite & Mikulski et al. (2013) \\
D148 & $339.5 \pm 3.1$ & $8 / 10$ & 80 & 2.3 & No (but close) & Cpx-Bt-Hbl monzonite & Mikulski et al. (2013) \\
M10 & $336.7 \pm 2.5$ & $14 / 18$ & 78 & 1.6 & Yes & Bt-Hbl granodiorite & Mikulski et al. (2013) \\
Podz2 & $334.4 \pm 3.3$ & $23 / 25$ & 92 & 0.55 & Yes & Bt-Opx-Cpx syenite (durbachite) & This study \\
M11 & $333.1 \pm 3.1$ & $7 / 8$ & 88 & 1.5 & Yes & Spessartite & Mikulski et al. (2013) \\
P9 & $331.5 \pm 2.6$ & $7 / 11$ & 64 & 1.1 & Yes & Bt-Hbl tonalite & Mikulski et al. (2013) \\
P33 & $303.3 \pm 4.2$ & $19 / 21$ & 90 & 0.35 & Yes & Hbl-Bt monzogranite & This study \\
\hline
\end{tabular}

For graphical age presentation and geographic position of dated rocks, see Fig. 2

${ }^{a}$ Dominant lithology observed by us and Wierzchołowski (1976)

${ }^{\mathrm{b}}$ Valid if $1-2 \sqrt{(2 /(N-1))}<\operatorname{MSWD}<1+2 \sqrt{(2 /(N-1))}$

spatial situation shows a parallel orientation to the intrusion. Of similar age is the Bardo tonalite apophysis and a porphyritic two-pyroxene basaltic andesite dyke (Figs. 1,2), which have an orientation perpendicular to the intrusion. In particular, the last shows that there was no large intrusive body to prevent melt upwelling; however, both possess mineralogical indications of magma mixing just before emplacement (i.e., different kinds of plagioclase with radically different An contents at the rims). Both rocks have a strong mantle-derived melt signature (Jokubauskas et al. 2014a, b). The porphyritic two-pyroxene dyke also contains a sieve-textured subset of pyroxenes, characteristic of rapid decompression, which raises the question of whether some magmas erupted at the surface. A volcanic component of the system is highly probable, considering that zircons from bentonites in the nearby Paprotnia Beds (Fig. 6) have yielded a similar $334 \pm 4$ Ma age (Kryza et al. 2008b). The volcanopluton connection is perfectly compatible with the regional evidence of bimodal volcanism of that age.

The youngest dated rocks from the early Carboniferous phase are the Chwalisław granodiorite and lamprophyre (spessartite), a tonalite dyke from Ptasznik hill (Mikulski et al. 2013) and the Podzamek melanocratic syenite dated in this study.

\section{Early Carboniferous spatial connection}

There are some intrusions in the Sudetes or Saxothuringian block reported to be of similar age and composition, such as the Meissen massif (Wenzel et al. 2000), and Niemcza granitoids (Pietranik et al. 2013). However, KZSI shows more affinity to calc-alkaline arc granitoids from the Teplá-Barrandian and Moldanubian units (Janoušek and Žák 2015), both in rock types and timing. In particular, the melanocratic syenite from Podzamek is closely similar to the durbachite from the Tábor intrusion (Janoušek and Žák 2015) and has certain similarities to the compositionally slightly different Třebič pluton (Kotkova 2007). Considering the redefined boundaries of the Teplá-Barrandian unit, extending it into the Sudetes (Franke 2012, 2014), and thus situating the Niemcza granitoids and KZSI on the same southern boundary of TBU, a similarity in tectonic position arises. Based on the age, regional-tectonic position and mineralogical compositions, these are rather geodynamically related early Carboniferous intrusions.

\section{Late Carboniferous spatial connection}

Based on the very simple Laski granodiorite lithology and the demonstration by Kryza et al. (2014) that the lithologically similar Krkonoše-Jizera pluton could have been formed in a very short time $(<1 \mathrm{Ma})$, we suggest that the $\sim 304 \mathrm{Ma}$ age rock could mark a similarly short-lived igneous event. It probably was induced by some mantle processes which show a temporal connection with the Sudetic Boundary Fault and Intra-Sudetic Fault, as similarly aged plutons and volcanic activity occur along these faults (Fig. 7). The Žulová Pluton ( $20 \mathrm{~km}$ to the SE), $291 \pm 5 \mathrm{Ma}$, is the youngest, followed by the Strzelin, Strzegom-Sobótka granitoids (40 and $75 \mathrm{~km}$ to the NNW), and finally the Krkonoše-Jizera pluton [the most recent precise date being $\sim 312 \mathrm{Ma}$, according to Kryza et al. (2014) and Kusiak et al. (2014)]; a connection between intrusions was discussed by Laurent et al. (2014). The age of $303.3 \pm 3.8 / 4.2 \mathrm{Ma}$ for the Laski monzogranite and the position of the KZSI fit perfectly into the migration of igneous activity along the major fault pattern from NW 
Fig. 6 The emplacement model, demonstrating the main evidence for post-emplacement tilt. However, the scheme is simplified and the real angles could be larger. a Map of the evidence, $\mathbf{b}$ reconstructed cross section. Note that most of the geological features in the figure are placed to meet the scale constraints-scale is the key in this scheme. The geological unit abbreviations are the same as in Fig. 1
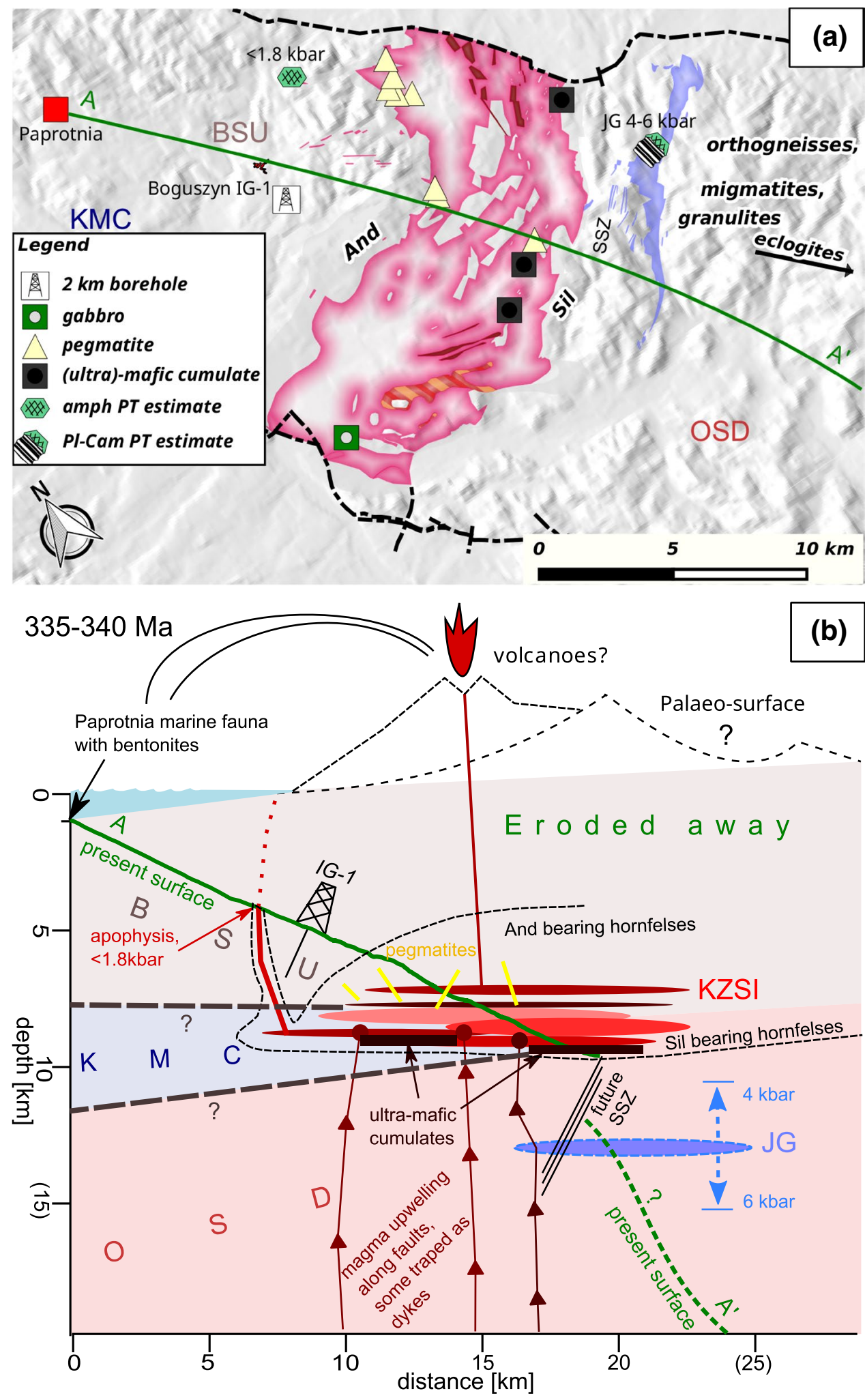

(Krkonoše-Jizera pluton) to the SE (Žulová pluton). It could mark the start of the extensional tectonic regime followed by late Carboniferous-Permian volcanism (Awdankiewicz et al. 2014; Turniak et al. 2014).

\section{Mechanisms of intrusion}

The lit-par-lit character of intrusion for the KZSI recognized by Lorenc $(1991,1994)$ has not been broadly accepted until 
Fig. 7 Map of the post-collisional igneous activity in the Sudetes. Abbreviations and sources of ages: KJG Karkonosze-Jizera granite (Kryza et al. 2014), SSM Strzegom-Sobótka Massif (Turniak et al. 2014), ŽP Žulova pluton (Laurent et al. 2014), SM Strzelin Massif (Oberc-Dziedzic and Kryza 2012), NSB North-Sudetic Basin (Awdankiewicz et al. 2014), ISB Intra-Sudetic Basin (Oplustil et al. 2016), SBF and ISF Sudetic boundary and intraSudetic faults. Note the pluton age progression from NW toward ES along the faults. The ages overlap with contemporaneous volcanism in the Sudetes

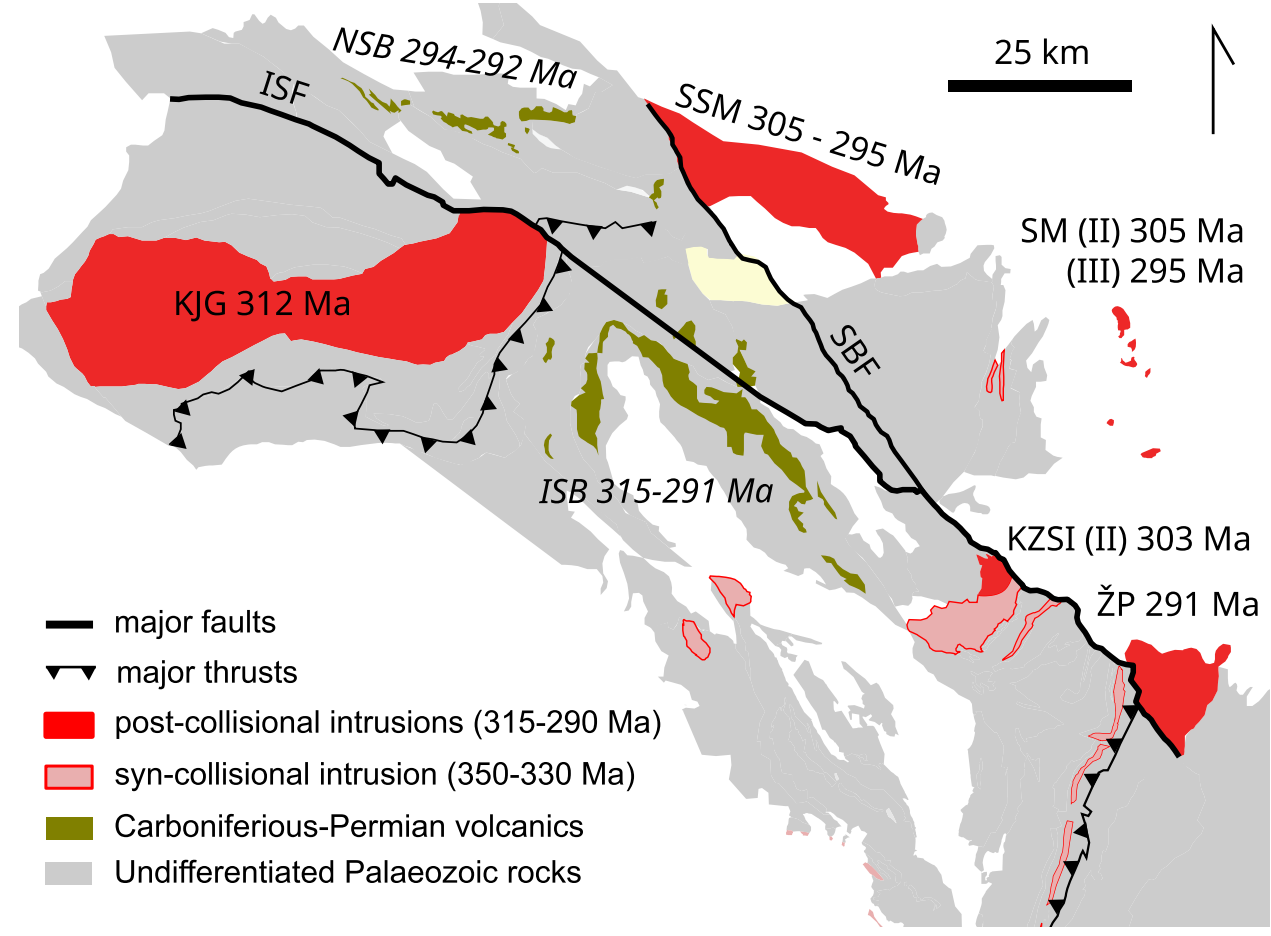

now. Wojciechowska's (1975) ballooning (three dome) model has been more favored (Mikulski et al. 2013; Mikulski and Williams 2013; Oberc-Dziedzic et al. 2015), or alternatively the intrusion was seen as a vertical structure without a base (i.e., Fig. 4 in Franke and Żelaźniewicz 2000).

Several observations favor a lit-par-lit, as opposed to ballooning, mechanism of intrusion. First, there is the well-defined fabric generally parallel to the intrusion (Wojciechowska 1975). Combined dating results suggest that the whole intrusion volume was never wholly liquid, and that magma upwelled in small batches. However, the timing and volume of melt input had to keep the temperatures of intrusion quite high, because there are no sharp boundaries and distinguishing separate pulses in the field is not possible. Similar mechanisms were described for the Spirit Mountain Batholith (Walker et al. 2007), intrusion from the Henry Mountains, Utah (Horsman et al. 2010) and the Barcroft pluton, California (Ernst 2013).

Combining published and our dating results, tonalitic/ dioritic (basaltic andesitic) melts were available throughout the whole history of the intrusion. Lamprophyric melt influx records appear for the second half of the early Carboniferous igneous phase [can be weakly tied with the dated Żelazno monzonites 420 Ma by Mikulski et al. (2013)], and taking into consideration sharply cutting dykes, based on field relationships, it could have continued shortly after the main plutonic magmatism. Basically the heterogeneity of the massif was created by the mixing and mingling of those coexisting magmas. The melt source could be the same and geochemical differences were caused mainly by different fluid concentrations, as presented, for example, by Davidson et al. (2007). The coexistence of two kinds of melt is well known in volcanic systems in subduction zones, such as the Aleutian arc, where water has been demonstrated to be the main cause of the differences (Zimmer et al. 2010). The Kłodzko-Złoty stock intrusion is rich in biotite and hornblende, suggesting high amounts of water in the melts. Furthermore, the thermobarometer of Ridolfi and Renzulli (2012), applied to amphiboles in the lamprophyres, has pointed to very high melt water contents (Jokubauskas et al. 2014a). The coexistence of basaltic and lamprophyre melts in young magmatic systems and the role of fluid in magma genesis are well documented (Lange and Carmichael 1990; Carmichael 2002; Barclay and Carmichael 2004). There are also some limited studies (Schulmann et al. 2009) which relate the ultra-potassic Variscan igneous activity directly to the arc tectonic setting. Continued production of amphiboleand biotite-rich granitoids in the KZSI for $20 \mathrm{Ma}$ would support such a suggestion.

\section{Post-emplacement tilting}

Post-emplacement tilting has been recorded from the Spirit Mountain batholith in southern Nevada, where the body was tilted by $40^{\circ}-50^{\circ}$ (Walker et al. 2007), and from the Tottabetsu Plutonic Complex, Hokkaido (Kamiyama et al. 2007). We suggest that the KZSI was also tilted post- emplacement; most of the evidence is shown in Fig. 6 and is as follows.

One of the most important pieces of evidence relates to bentonites dated to $334 \pm 4 \mathrm{Ma}$ (Kryza et al. 2008b) 
and the Jawornik granitoids dated at $\sim 350$ and $\sim 340 \mathrm{Ma}$ (Białek 2014). The first marks the presence of a marine fauna (Muszer and Uglik 2013) whilst the second records a middle crustal pressure of 4-6 kbar (Białek 2001, 2014). Because of the similar ages, a plane in $3 \mathrm{D}$ space can be drawn, estimating where the present day surface was at 334-344 Ma. Furthermore, the bentonites could possibly have originated from the same magma system as the KSZI. As an example, such a coexistence of volcanic and plutonic systems was reported in the Tuscana Magmatic Province, Italy, by Gagnevin et al. (2010) where pluton and coeval volcanic systems were active between 7 and $8 \mathrm{Ma}$ (Gagnevin et al. 2008).

Another important line of evidence comes from our thermobarometric study (Jokubauskas et al. 2013, 2014b), pointing to quite shallow depths; $<1.8 \mathrm{kbar}$ for the Bardo apophysis, the mostly NW-situated plutonic rocks, suggesting that the main intrusion levels have been at an average crustal depth corresponding to slightly more than $2 \mathrm{kbar}$. Granophyric textures have been observed only on the northwestern side, which is consistent with shallower depths for that side being the top part of the intrusion. Most of the pegmatites noted by Wierzchołowski (1976) concentrate on the NW side of the intrusion, whilst (ultra)-mafic cumulates are found on and near the SE boundary only. In the 1970s, it was hypothesized that the intrusion is flat-lying (Wojciechowska 1975), so the "Boguszyn IG-1" 2-km borehole was drilled for confirmation at BSU. Only Bardo sedimentary rocks were found (PGI-NRI). Furthermore, a mineralogical pattern can be recognized in the hornfelses, where according to Bagiński (2002) and Wierzchołowski (1976), no sillimanite has been found on the NW border, only andalusite. Another important line of evidence is the metamorphic facies of the OSD, changing in a quite simple sequence from sillimanite-bearing gneisses to granulites and migmatites up to eclogites.

Previously, the 330-350 Ma age in eclogites and other eastern HP Orica-Śnieżnik Dome rocks (Bröcker et al. 2009) was interpreted as being caused purely by a tectonothermal event (Żelaźniewicz et al. 2014). Considering the pre-tilt position of the intrusion where it would have been situated above the eastern OSD and the very good age correlation between the KZSI and OSD (350-330 Ma) it is quite plausible that migrating melts would have raised the temperature of the crust (OSD). In such a scenario the sudden termination of dates at $330 \mathrm{Ma}$ in both KZSI and metamorphic rocks could be explained by the termination of melt production in the mantle followed by a sudden close-down of the magma system. Moreover, the abundance of 350-330 Ma ages in the metamorphic rocks would also agree with the main magmatic activity age. The younger ages $(\sim 300 \mathrm{Ma})$ in the KZSI and Żulova granites indicate that the region was still buried at least to middle or upper crust levels.
Reconstructed post-magmatic tilting of a small crustal segment can happen in both extensional and compressional tectonic settings. In the case of the KZSI, palaeontological evidence from the Paprotnia Beds (Muszer and Uglik 2013) shows that after ca. $334 \mathrm{Ma}$, recorded by bentonites, the eastern bank of the Intra-Sudetic Basin started to be lifted up, going from a deep to shallow sea level, and later emerging as land. Together with evidence from the SE side of KZSI, this suggests that the tilting was due to a compression-induced uplift of the SE side of intrusion rather than to subsidence of the NW side. The timing of the tilting could have been related to a change from a dextral to sinistral tectonic regime, which is recorded in both the tectonised rocks in the intrusion (ES part) and the Skrzynka shear zone (Cymerman 1996, 2000, 2016; Wierzchołowski 1976), and had to follow very shortly after the early Carboniferous magmatic phase.

\section{Conclusions}

- The KZSI was emplaced in two main episodes:

- multi-pulse early Carboniferous (350-330 Ma) episode, which correlates with other similar intrusions of BM situated on or near the SE boundary of Teplá-Barrandian unit;

- short-lived late Carboniferous ( $304 \mathrm{Ma})$ episode, which spatially and timely fits into NW to SE-moving plutonic activity in Sudetes at the late Carboniferous-Permian transition.

- The intrusion grew by lit-par-lit injections of small magma batches. The lithological diversity characterizing the intrusion has resulted from extensive magma mixing between lamprophyric and basaltic primitive melts and their fractionates.

- Post-emplacement tilting of the intrusion has revealed a section through the intrusion. A possible connection between the KZSI and the age equivalent bentonites in the Paprotnia Beds is proposed.

Acknowledgements We thank Wolfgang Franke, Michael Bröcker, Albrecht von Quadt and anonymous reviewers for very helpful comments on the manuscript. We also thank Marek Awdankiewicz for many useful discussions on the KZSI and dyke interaction and Zbigniew Czupyt for the help in SHRIMP sample preparation. This study was partially financed by Polish National Science Center (NCN), Grant no. NN307 634840. This work was partially performed in the NanoFun laboratories in the Faculty of Geology co-financed by the European Regional Development Fund within the Innovation Economy Operational Program, project no. POIG.02.02.00-00-025/09/. 
Open Access This article is distributed under the terms of the Creative Commons Attribution 4.0 International License (http://creativecommons.org/licenses/by/4.0/), which permits unrestricted use, distribution, and reproduction in any medium, provided you give appropriate credit to the original author(s) and the source, provide a link to the Creative Commons license, and indicate if changes were made.

\section{References}

Aleksandrowski P (1998) The Intra-Sudetic fault zone and the Variscan strike-slip tectonics in the West Sudetes. Geolines 6:6-8

Aleksandrowski P, Mazur S (2002) Collage tectonics in the northeasternmost part of the Variscan belt: the Sudetes, Bohemian Massif. Geol Soc Lond Spec Publ 201:237-277. https://doi. org/10.1144/GSL.SP.2002.201.01.12

Awdankiewicz M (2007) Late Palaeozoic lamprophyres and associated mafic subvolcanic rocks of the Sudetes (SW Poland): petrology, geochemistry and petrogenesis. Geologia Sudetica 39:11-97

Awdankiewicz M, Kryza R, Szczepara N (2014) Timing of postcollisional volcanism in the eastern part of the Variscan belt: constraints from SHRIMP zircon dating of Permian rhyolites in the North-Sudetic Basin (SW Poland). Geol Mag 151:611-628. https://doi.org/10.1017/S0016756813000678

Bachliński R, Bagiński B (2007) Kłodzko-Złoty Stok granitoid massif. Granitoids in Poland. Archiwium Mineralogiczne, pp 261-273

Bagiński B (2002) Contact metamorphism induced by the KłodzkoZłoty Stok Intrusion (Sudetes, Poland). Mineral Soc Pol Spec Pap 20:57-59

Balk R (1925) Primary structure of granite massives. Geol Soc Am Bull 36:679-696. https://doi.org/10.1130/GSAB-36-679

Barclay J, Carmichael ISE (2004) A hornblende basalt from Western Mexico: water-saturated phase relations constrain a pressure-temperature window of eruptibility. J Petrol 45:485-506. https://doi.org/10.1093/petrology/egg091

Beyrich E, Rose R, Roth I, Runge W (1865) Geologische Karte von dem Niederschlesischen Gebirge und den angrenzenden Gegenden. Schropp Land \& Karte, Berlin. http://www.deutschefotothek.de/documents/obj/90010907

Białek D (2001) Mineralogy and Thermobarometry of the Jawornickie Granitoids. Rychlebske Hory. Geolines 13:49

Białek D (2014) SHRIMP U-Pb zircon geochronology of the Jawornik granitoids (West Sudetes, Poland). Geologia Sudetica 42:4

Black LP, Kamo SL, Allen CM et al (2004) Improved 206Pb/238U microprobe geochronology by the monitoring of a trace-element-related matrix effect; SHRIMP, ID-TIMS, ELA-ICPMS and oxygen isotope documentation for a series of zircon standards. Chem Geol 205:115-140. https://doi.org/10.1016/j. chemgeo.2004.01.003

Bojanowski MJ, Barczuk A, Wetzel A (2014) Deep-burial alteration of early-diagenetic carbonate concretions formed in Palaeozoic deep-marine greywackes and mudstones (Bardo Unit, Sudetes Mountains, Poland). Sedimentology 61:1211-1239. https://doi. org/10.1111/sed.12098

Bowes DR, Košler J (1993) Geochemical comparison of the subvolcanic appinite suite of the British Caledonides and the durbachite suite of the Central European Hercynides: evidence for associated shoshonitic and granitic magmatism. Mineral Petrol 48:47-63. https://doi.org/10.1007/BF01164908

Bröcker M, Klemd R, Cosca M et al (2009) The timing of eclogite facies metamorphism and migmatization in the Orlica-Śnieżnik complex, Bohemian Massif: constraints from a multimethod geochronological study. J Metamorph Geol 27:385-403. https://doi.org/10.1111/j.1525-1314.2009.00823.x

Budzyń B, Jastrzębski M (2016) Monazite stability and the maintenance of Th-U-total $\mathrm{Pb}$ ages during post-magmatic processes in granitoids and host metasedimentary rocks: a case study from the Sudetes (SW Poland). Geol Q 60:106-123. https:// doi.org/10.7306/gq.1254

Budzyń B, Jastrzębski M, Kozub-Budzyń GA, Konečný P (2015) Monazite $\mathrm{Th}-\mathrm{U}$-total $\mathrm{Pb}$ geochronology and $\mathrm{P}-\mathrm{T}$ thermodynamic modelling in a revision of the HP-HT metamorphic record in granulites from Stary Gierałtów (NE OrlicaŚnieżnik Dome, SW Poland). Geol Q 59:700-717. https://doi. org/10.7306/gq. 1232

Carmichael IS (2002) The andesite aqueduct: perspectives on the evolution of intermediate magmatism in west-central (10599W) Mexico. Contrib Miner Petrol 143:641-663. https://doi. org/10.1007/s00410-002-0370-9

Chopin F, Schulmann K, Skrzypek E et al (2012) Crustal influx, indentation, ductile thinning and gravity redistribution in a continental wedge: building a Moldanubian mantled gneiss dome with underthrust Saxothuringian material (European Variscan belt). Tectonics 31:TC002951. https://doi.org/10.1029/2011TC002951

Cwojdziński S (1977) Detailed geological map of Sudetes, 1:25000, sheet: Złoty Stok

Cwojdziński S (1979) Evolution of macroenclaves, study based on intrusive and postintrusive tectonics of Kłodzko-Złoty Stok granitoid massif. Wroclaw University, Wrocław

Cwojdziński S (1981) Pre-granitoid semi-lamprophyre at Rogówek (Kłodzko-Złoty Stok granitoid massif). Geol Q 25:31-40

Cymerman Z (1996) The Złoty Stok-Trzebieszowice regional shear zone: the boundary of terranes in the Góry Złote Mts. (Sudetes). Geol Q 40:89-118. https://gq.pgi.gov.pl/article/view/8167

Cymerman Z (2000) Palaeozoic orogeneses in the Sudetes: a geodynamic model. Geol Q 44:59-80. https://gq.pgi.gov.pl/article/ view/8032

Cymerman Z (2016) The Orlica-Śnieżnik Dome in the light of tectonic considerations. Przegląd Geologiczny 64:814-830

Dallmeyer RD, Franke W, Weber K (eds) (1995) Pre-Permian geology of Central and Eastern Europe. Springer, Berlin

Davidson J, Turner S, Handley H et al (2007) Amphibole "sponge". in arc crust? Geology 35:787-790. https://doi.org/10.1130/ G23637A.1

Emerle-Tubielewicz H (1979) Detailed geological map of Sudetes, sheet: Kłodzko, 1:25000. Polish Geological Institute, National Research Institute, Warsaw

Ernst WG (2013) Petrogenesis of the Barcroft pluton, northern WhiteInyo Mountains, east-central California. Contrib Miner Petrol 165:419-435. https://doi.org/10.1007/s00410-012-0815-8

Finckh L, Meister F, Fischer G, Bederke E (1942) Geologische Karte des deutschen Reches 1:25 000. H. 343. Blatt Glatz, Königshein, Reichenstein und Landeck/Erläuterungen/. Reichsamt. für Bodenforschung, Berlin

Finger F, Steyrer HP (1990) I-type granitoids as indicators of a late Paleozoic convergent ocean-continent margin along the southern flank of the central European Variscan orogen. Geology 18:1207. 10.1130/0091-7613(1990)018<1207:ITGAIO>2.3.CO;2

Franke W (2000) Orogenic processes: quantification and modelling in the Variscan belt. Geological Society of London, London

Franke W (2006) The Variscan orogen in Central Europe: construction and collapse. Geol Soc Lond Mem 32:333-343. https://doi. org/10.1144/GSL.MEM.2006.032.01.20

Franke W (2012) Comment on Dörr and Zulauf: Elevator tectonics and orogenic collapse of a Tibetan-style plateau in the European Variscides: the role of the Bohemian shear zone. Int J Earth Sci (Geol Rundsch) (2010) 99:299-325. Int J Earth Sci (Geol Rundsch) 101:2027-2034. https://doi.org/10.1007/s00531-012-0766-3 
Franke W (2014) Topography of the Variscan orogen in Europe: failednot collapsed. Int J Earth Sci (Geol Rundsch) 103:1471-1499. https://doi.org/10.1007/s00531-014-1014-9

Franke W, Żelaźniewicz A (2000) The eastern termination of the Variscides: terrane correlation and kinematic evolution. Geol Soc Lond Spec Publ 179:63-86. https://doi.org/10.1144/GSL. SP.2000.179.01.06

Gagnevin D, Daly JS, Whitehouse MJ et al (2008) Zircon as proxy of magma differentiation and mixing in the Tuscan Magmatic Province (Italy). Geochim Cosmochim Acta 72:A288. https:// doi.org/10.1016/j.gca.2008.05.010

Gagnevin D, Daly JS, Kronz A (2010) Zircon texture and chemical composition as a guide to magmatic processes and mixing in a granitic environment and coeval volcanic system. Contrib Miner Petrol 159:579-596. https://doi.org/10.1007/s00410-009-0443-0

Gao Y-Y, Li X-H, Griffin WL et al (2014) Screening criteria for reliable $\mathrm{U}-\mathrm{Pb}$ geochronology and oxygen isotope analysis in uraniumrich zircons: a case study from the Suzhou A-type granites, SE China. Lithos 192-195:180-191. https://doi.org/10.1016/j. lithos.2014.02.002

Gordon SM, Schneider DA, Manecki M, Holm DK (2005) Exhumation and metamorphism of an ultrahigh-grade terrane: geochronometric investigations of the Sudete Mountains (Bohemia), Poland and Czech Republic. J Geol Soc 162:841-855

Gunia P, Wojciechowska I (2002) Geochemistry of hornblende-bearing pyroxenites within granitoids of the Kłodzko-Złoty Stok intrusion. Mineral Soc Pol Spec Pap 20:97-99

Hamdy M (2001) Mineral chemistry of the phlogopite-bearing olivine two-pyroxene hornblendite from Droszków in the Kłodzko-Złoty Stok granitoid intrusion (SW Poland). Mineral Soc Pol Spec Pap 19:64-66

Holub FV, Żaba J (2003) Geochemical variability of the Kłodzko-Złoty Stok Massif: possible role of multiple mafic end-members of hybrid granitoids. Geolines 16:158-159

Horsman E, Morgan S, de Saint-Blanquat M et al (2010) Emplacement and assembly of shallow intrusions from multiple magma pulses, Henry Mountains, Utah. In: Geological Society of America special papers. Geological Society of America, pp 117-132

Hunter JD (2007) Matplotlib: a 2D graphics environment. Comput Sci Eng 9:90-95. https://doi.org/10.1109/MCSE.2007.55

Janoušek V, Žák J (eds) (2015) Euroganites 2015: Variscan plutons of the Bohemian Massif. In: Post-conference field trip following the 26th IUGG general assembly in Prague. Czech Geological Survey, Prague

Jastrzębski M (2012) New insights into the polyphase evolution of the Variscan suture zone: evidence from the Staré Město Belt, NE Bohemian Massif. Geol Mag 149:945-963. https://doi. org/10.1017/S0016756812000040

Jastrzębski M, Żelaźniewicz A, Nowak I et al (2010) Protolith age and provenance of metasedimentary rocks in Variscan allochthon units: U-Pb SHRIMP zircon data from the Orlica-Śnieżnik Dome, West Sudetes. Geol Mag 147:416-433. https://doi. org/10.1017/S0016756809990501

Jastrzębski M, Żelaźniewicz A, Majka J et al (2013) Constraints on the Devonian-Carboniferous closure of the Rheic Ocean from a multi-method geochronology study of the Staré Město Belt in the Sudetes (Poland and the Czech Republic). Lithos 170-171:5472. https://doi.org/10.1016/j.lithos.2013.02.021

Jokubauskas P, Bagiński B, Macdonald R, Awdankiewicz M (2013) Modeling the Kłodzko-Złoty Stok magma system using amphibole and two pyroxene geothermobarometry. Miner Spec Pap $41: 47$

Jokubauskas P, Awdankiewicz M, Bagiński B, Macdonald R (2014a) The origin of lamprophyres and related dykes in the
Kłodzko-Złoty Stok pluton-insights from isotope chemistry and thermobarometry. Mineral Spec Pap 42:61-62

Jokubauskas P, Bagiński B, Macdonald R (2014b) The apophyses and "apophyses" of the Kłodzko-Złoty Stok intrusion-amphibole and 2 pyroxene thermobarometry. Mineral Spec Pap 42:60

Jokubauskas P, Bagiński B, Macdonald R, Awdankiewicz M (2014c) Kłodzko-Złoty Stok intrusion: field trip guide. Mineral Spec Pap 42:127-134

Kamiyama H, Nakajima T, Kamioka H (2007) Magmatic stratigraphy of the tilted Tottabetsu plutonic complex, Hokkaido, North Japan: magma chamber dynamics and pluton construction. J Geol 115:295-314. https://doi.org/10.1086/512754

Klemd R, Bröcker M (1999) Fluid influence on mineral reactions in ultrahigh-pressure granulites: a case study in the Śnieżnik Mts. (West Sudetes, Poland). Contrib Miner Petrol 136:358-373. https://doi.org/10.1007/s004100050544

Klomínský J, Jarchovský T, Rajpoot GS (2010) Atlas of plutonic rocks and orthogneisses in the Bohemian Massif. Czech Geological Survey, Prague

Kotkova J (2007) High-pressure granulites of the Bohemian Massif: recent advances and open questions. J Geosci 52:45-71. https:// doi.org/10.3190/jgeosci.006

Kryza R, Mazur S, Oberc-Dziedzic T (2004) The Sudetic geological mosaic: Insights into the root of the Variscan orogen. Przegląd Geologiczny 52:761-771

Kryza R, Mazur S, Aleksandrowski P (2008a) Pre-Late Devonian unconformity in the Kłodzko area excavated: a record of EoVariscan metamorphism and exhumation in the Sudetes. Geologia Sudetica 32:127-137

Kryza R, Muszer J, August C et al (2008b) Lower Carboniferous bentonites in the Bardo Structural Unit (central Sudetes): geological context, petrology and palaeotectonic setting. Geologia Sudetica 40:19-31

Kryza R, Pin C, Oberc-Dziedzic T et al (2014) Deciphering the geochronology of a large granitoid pluton (Karkonosze Granite, SW Poland): an assessment of $\mathrm{U}-\mathrm{Pb}$ zircon SIMS and $\mathrm{Rb}-\mathrm{Sr}$ wholerock dates relative to U-Pb zircon CA-ID-TIMS. Int Geol Rev 56:756-782. https://doi.org/10.1080/00206814.2014.886364

Kusiak MA, Williams IS, Dunkley DJ et al (2014) Monazite to the rescue: $\mathrm{U}-\mathrm{Th}-\mathrm{Pb}$ dating of the intrusive history of the composite Karkonosze pluton, Bohemian Massif. Chem Geol 364:76-92. https://doi.org/10.1016/j.chemgeo.2013.11.016

Lange RA, Carmichael ISE (1990) Hydrous Basaltic andesites associated with minette and related lavas in Western Mexico. J Petrol 31:1225-1259. https://doi.org/10.1093/petrology/31.6.1225

Laurent A, Janoušek V, Magna T et al (2014) Petrogenesis and geochronology of a post-orogenic calc-alkaline magmatic association: the Žulová Pluton, Bohemian Massif. J Geosci 59:415-440. https://doi.org/10.3190/jgeosci.176

Lorenc MW (1991) Uwagi o genezie intruzji kłodzko-złotostockiej (Studium porównawcze na bazie enklaw). Archivum Mineralogiae 47:79-98

Lorenc MW (1994) Role of basic magmas in the granitoid evolution (a comparative study of some hercynian massifs). Geologia Sudetica 28:1-130

Ludwig RK (2009) SQUID 2: a user's manual. rev. 12. Berkeley Geochron Ctr Spec Pub 5:110

Ludwig RK (2012) Isoplot 3.75: a user's manual. Berkeley Geochron CtrSpec Pub 5:75

Matte P, Maluski H, Rajlich P, Franke W (1990) Terrane boundaries in the Bohemian Massif: result of large-scale Variscan shearing. Tectonophysics 177:151-170. https://doi. org/10.1016/0040-1951(90)90279-H

Mazur S, Turniak K, Bröcker M (2004) Neoproterozoic and CambroOrdovician magmatism in the Variscan Klodzko Metamorphic 
Complex (West Sudetes, Poland): new insights from $\mathrm{U} / \mathrm{Pb}$ zircon dating. Int J Earth Sci (Geol Rundsch) 93:758-772. https://doi. org/10.1007/s00531-004-0417-4

Mazur S, Aleksandrowski P, Kryza R, Oberc-Dziedzic T (2006) The Variscan Orogen in Poland. Geol Q 50:89-118

Mazur S, Aleksandrowski P, Turniak K, Awdankiewicz M (2007) Geology, tectonic evolution and Late Palaeozoic magmatism of Sudetes-an overview. In: Kozłowski A, Wiszniewska J (eds) Granitoids in Poland. Geology departament of University of Warsaw and Polish Geological Institute-National Research Institute, Warsaw, pp 59-87

Mikulski SZ, Williams IS (2013) Zircon U-Pb ages of granitoid apophyses in the western part of the Kłodzko-Złoty Stok Granite Pluton (SW Poland). Geol Q 58:251-262. https://doi. org/10.7306/gq.1141

Mikulski SZ, Williams IS, Bagiński B (2013) Early Carboniferous (Viséan) emplacement of the collisional Kłodzko-Złoty Stok granitoids (Sudetes, SW Poland): constraints from geochemical data and zircon U-Pb ages. Int J Earth Sci (Geol Rundsch) 102:1007-1027. https://doi.org/10.1007/s00531-012-0852-6

Muszer A (1992) Mineralized pyroxenites from the vicinity of Złoty Stok and their relrelations with lineaments. Acta Universitatis Wratislaviensis Prace Geologiczno-Mineralogiczne XXVIII:69-77

Muszer J, Uglik M (2013) Palaeoenvironmental reconstruction of the Upper Visean Paprotnia Beds (Bardo Unit, Polish Sudetes) using ichnological and palaeontological data. Geol Q 57:365-384. https://doi.org/10.7306/gq.1095

Oberc-Dziedzic T, Kryza R (2012) Late stage Variscan magmatism in the Strzelin Massif (SW Poland): SHRIMP zircon ages of tonalite and Bt-Ms granite of the Gęsiniec intrusion. Geol Q $56: 225-236$

Oberc-Dziedzic T, Kryza R, Pin C (2015) Variscan granitoids related to shear zones and faults: examples from the Central Sudetes (Bohemian Massif) and the Middle Odra Fault Zone. Int J Earth Sci (Geol Rundsch) 104:1139-1166. https://doi.org/10.1007/ s00531-015-1153-7

Oplustil S, Schmitz M, Kachlik V, Stamberg S (2016) Re-assessment of lithostratigraphy, biostratigraphy, and volcanic activity of the Late Paleozoic Intra-Sudetic, Krkonose-Piedmont and Mnichovo Hradiste basins (Czech Republic) based on new U-Pb CA-IDTIMS ages. Bull Geosci 91:399-432

PGI-NRI Boreholes (2017) Central Geological Database. http://otworywiertnicze.pgi.gov.pl/Details/Information/28694. Accessed 20 Feb 2017

Pietranik A, Storey C, Kierczak J (2013) The Niemcza diorites and monzodiorites (Sudetes, SW Poland):a record of changing geotectonic setting at ca. $340 \mathrm{Ma}$. Geol Q 57:325-334. https://doi. org/10.7306/gq. 1084

Ridolfi F, Renzulli A (2012) Calcic amphiboles in calc-alkaline and alkaline magmas: thermobarometric and chemometric empirical equations valid up to $1,130{ }^{\circ} \mathrm{C}$ and $2.2 \mathrm{GPa}$. Contrib Miner Petrol 163:877-895. https://doi.org/10.1007/s00410-011-0704-6

Rock NMS (1991) Lamprophyres. Blackie and Son Ltd, Glasgow

Schulmann K, Gayer R (2000) A model for a continental accretionary wedge developed by oblique collision: the NE Bohemian Massif. J Geol Soc 157:401-416. https://doi.org/10.1144/jgs.157.2.401

Schulmann K, Konopásek J, Janoušek V et al (2009) An Andean type Palaeozoic convergence in the Bohemian Massif. C R Geosci 341:266-286. https://doi.org/10.1016/j.crte.2008.12.006

Seifert W, Kramer W (2003) Accessory titanite: an important carrier of zirconium in lamprophyres. Lithos 71:81-98. https://doi. org/10.1016/j.lithos.2003.07.002

Skrzypek E, Lehmann J, Szczepański J et al (2014) Time-scale of deformation and intertectonic phases revealed by $\mathrm{P}-\mathrm{T}-\mathrm{D}-\mathrm{t}$ relationships in the orogenic middle crust of the Orlica-Śnieżnik Dome, Polish/Czech Central Sudetes. J Meta Geol 32:981-1003. https://doi.org/10.1111/jmg.12103

Turniak K, Mazur S, Domańska-Siuda J, Szuszkiewicz A (2014) SHRIMP U-Pb zircon dating for granitoids from the Strzegom-Sobótka Massif, SW Poland: Constraints on the initial time of Permo-Mesozoic lithosphere thinning beneath Central Europe. Lithos 208-209:415-429. https://doi.org/10.1016/j. lithos.2014.09.031

Ventura GD, Bellatreccia F, Williams CT (1999) Zr- and LREE-rich titanite from Tre Croci, Vico Volcanic complex (Latium, Italy). Mineral Mag 63:123-130

von Raumer JF, Finger F, Veselá P, Stampfli GM (2014) DurbachitesVaugnerites-a geodynamic marker in the central European Variscan orogen. Terra Nova 26:85-95. https://doi.org/10.1111/ ter.12071

Walker BA, Miller CF, Lowery Claiborne L et al (2007) Geology and geochronology of the Spirit Mountain batholith, southern Nevada: implications for timescales and physical processes of batholith construction. J Volcanol Geotherm Res 167:239-262. https://doi.org/10.1016/j.jvolgeores.2006.12.008

Wenzel T, Oberhänsli R, Mezger K (2000) K rich plutonic rocks and lamprophyres from Meissen Massif (northern Bohemian Massif): Geochemical evidence for variably enriched lithospheric mantle source. Neues Jahrbuch für Mineralogie Abhandlungen 175:249-293

White LT, Ireland TR (2012) High-uranium matrix effect in zircon and its implications for SHRIMP U-Pb age determinations. Chem Geol 306-307:78-91. https://doi.org/10.1016/j. chemgeo.2012.02.025

Wierzchołowski B (1976) Granitoids of the Kłodzko-Złoty Stok massif and their contact influence on the country rocks (petrographic characteristics). Geologia Sudetica 11:7-147

Wierzchołowski B (1977) Dyke rocks of the Kłodzko-Złoty Stok granitoid massif. Geologia Sudetica XII:7-28

Wierzchołowski B (2003) Potassium-rich dyke rock of Rogówek (Sudetes,Poland). Arch Miner LIV:77-97

Wieser T (1958) Petrotektonika zachodniej części masywu intruzywnego Kłodzko-Złoty Stok. Geol Q 2:673-687

Williams IS (1998) U-Th-Pb geochronology by ion microprobe. In: McKibben MA, Shanks WC, Ridley WI (eds) Applications of microanalytical techniques to understanding mineralizing processes. Society of Economic Geologists, Littleton, pp 1-35

Williams IS, Claesson S (1987) Isotopic evidence for the Precambrian provenance and Caledonian metamorphism of high grade paragneisses from the Seve Nappes, Scandinavian Caledonides. Contrib Miner Petrol 97:205-217. https://doi.org/10.1007/ BF00371240

Winchester JA, Pharaoh TC, Verniers J (2002) Palaeozoic amalgamation of Central Europe: an introduction and synthesis of new results from recent geological and geophysical investigations. Geol Soc Lond Spec Publ 201:1-18. https://doi.org/10.1144/ GSL.SP.2002.201.01.01

Wojciechowska I (1975) Tectonics of the Kłodzko-Złoty Stok granitoids massif and its country rocks in the light of mesostructural investigations. Geologia Sudetica 10:61-121

Wojciechowska I (2002) The geotectonic position of the KłodzkoZłoty Stok granitoids. Miner Soc Pol Spec Pap 20:231-233

Żelaźniewicz A, Jastrzębski M, Redlińska-Marczyńska A, Szczepański J (2014) The Olica-Śnieżnik Dome, the Sudetes, in 2002 and 12 years later. Geologia Sudetica 42:105-123

Zimmer MM, Plank T, Hauri EH et al (2010) The role of water in generating the calc-alkaline trend: new volatile data for aleutian magmas and a new tholeiitic index. J Petrol. https://doi. org/10.1093/petrology/egq062 